\title{
Green Workplace Behaviour in Saudi Arabia: The Case of EnviroCo
}

\author{
Nadia Abdulghaffar ${ }^{1}$ \\ ${ }^{1}$ Faculty of Economics and Administration, King Abdulaziz University, Jeddah, Kingdom of Saudi Arabia \\ Correspondence: Nadia Abdulghaffar, Faculty of Economics and Administration, King Abdulaziz University, \\ Jeddah, Kingdom of Saudi Arabia. E-mail: nabdulghaffar@kau.edu.sa
}

Received: December 20, 2016 Accepted: January 12, 2017 Online Published: January 25, 2017

doi:10.5539/jms.v7n1p19 URL: http://dx.doi.org/10.5539/jms.v7n1p19

\begin{abstract}
In order to enhance sustainability in the workplace, recent research has focused on the practices which can promote employees' green behaviour. However, there is little work that examines the extent to which companies use HRM practices to foster green bahaviour. This study has investigated this issue through a survey conducted in a government agency in Saudi Arabia. Overall, the findings suggest that senior managers are aware of the importance of green workplace behaviour and recognize that a certain number of HRM practices can promote and support this behaviour. However, these practices are not used effectively and senior managers can only marginally foster pro-environmental behaviour in their organization.
\end{abstract}

Keywords: green workplace behaviour, sustainability, environmental management, HRM practices

\section{Introduction}

\subsection{Green Behaviour in the Workplace}

In recent years, organizations have come under increasing pressure to address the long term consequences of environmental degradation and pollution and to improve their responsiveness and stewardship (Aguinis \& Glavas, 2012). While governments are forcing companies to comply with environmental legislation and regulations, organizations around the world have gradually recognized the benefits and opportunities associated to environmental sustainability, both in terms of reputation and increased competitive advantage, and strive to develop more sustainable working practices. These practices are often referred in the literature as "green practices" (Renwick et al., 2013) and have seen companies setting up formal and informal environmental management systems (Darnall et al., 2008). Such practices may include, as suggested by Olson (2008), placing recycling containers for drinks, cans and paper throughout the workplace, encouraging people to reduce waste, turn off lights and computers, making people aware of water and energy conservation, developing training programmes about environmental issues, the risk of global warming and how the business environment could reduce the effects of its activities.

However, these initiatives alone are insufficient (Robertson \& Barling, 2013). Indeed, scholars have claimed that environmental problems are often caused by human behaviour and therefore organizations should put more efforts in changing it (Daily et al., 2009; Ones \& Dilchert, 2012). Hence, fostering and promoting employees' "green behaviour" (Andersson et al., 2013) within organizations is now critical. Specifically, green behaviour has been defined as one that minimises harm to the environment as much as possible, or even benefits it (Steg \& Vlek, 2009). For example, organizations should put more efforts in encouraging behaviours such as recycling, conservation and waste reduction. These behaviours will not only contribute to environmental sustainability and the greening of working practices, but they will also prevent further degradation.

While the need to promote more green behaviour is well recognized in the literature, there is still scarce research on environmental sustainability and on how to change effectively workplace behaviours (Russell \& Griffiths, 2008; Huffman et al., 2009; Jackson \& Seo, 2010). Specifically, the literature has focused more at the organization level and has devoted less attention to understanding the role and impact of organizational practices in influencing employees' behaviour. Further, research has only sparingly attempted to shed light on employee behaviour and its role in advancing responsiveness and environmental sustainability (Ones \& Dilchert, 2012).

The paper intends to investigate the role of leadership and the practices (especially human resource management practices) used in organizations to encourage employees' green behaviour. Indeed, leaders have been found to influence a range of organizational outcomes, such as employees' attitudes and commitment, safety and 
environmental performance (Ramus \& Steger, 2000; Barling et al., 2010). In doing this, we respond to recent calls in the literature to integrate environmental sustainability with HRM practices (Jabbour \& Santos, 2008; Renwick et al., 2013). Specifically, the paper will attempt to:

- Identify the perceptions of senior managers and staff in relation to the concept and principles of green environment in the workplace;

- Identify the methods used by senior managers to encourage staff green behavior in the workplace environment;

- Identify the main green working practices put in place by the senior management (e.g., sound and safe, healthy and environmentally friendly workplace).

- Provide recommendations which can assist senior managers in fostering green workplace behaviour and in adopting more effective green practices.

These issues are explored through a survey conducted in a government agency (EnviroCo) located in Saudi Arabia. Overall, the findings indicate that the leadership at EnviroCo has not put enough efforts to encourage and promote employees' green behaviour to the extent that would be beneficial. While a number of HRM practices have been recognized as important by both senior managers and lower level staff, these are not used effectively. Therefore, managers at EnviroCo could make greater use of these practices to promote pro-environmental behaviour among staff.

\subsection{Theoretical Background}

This section provides an overview of the main HRM practices which are mentioned in the literature and which contribute towards fostering green behaviour within organizations. The following practices are outlined: management development and green leadership; involving and engaging employees; employee training; and environmental awareness. The section also includes a discussion about a number of initiatives which together with HRM practices encourage green behaviour.

\subsubsection{Management Development and Green Leadership}

The importance of leadership in driving environmental performance is well documented in the literature (Ramus, 2002; Zibarras \& Ballinger, 2011; Robertson \& Barling, 2013). Green leaders place environmental sustainability at the centre of their initiatives and policies (Robertson \& Barling, 2013) and embed it within the organizational culture ensuring values and assumptions are communicated throughout the organization (Govindarajulu \& Daily, 2004; Ones \& Dilchert, 2012; Robrtson \& Barling, 2013). They also promote environmental awareness within the employees and encourage their involvement in decision-making (Cox et al., 2012). In this respect, Robertson \& Barling (2013) found not only that leaders directly influence employees' green behaviour, but also they increase employee engagement with environmental initiatives.

\subsubsection{Involving and Engaging Employees}

Environmental initiatives taken by the management without employee involvement are going to be less successful. A number of studies have shown that environmental performance has improved through efficient resource usage, waste and pollution reduction in the workplace (May \& Flannery, 1995; Denton, 1999; Florida \& Davison, 2001). In particular, Renwick et al. (2013) argue that employee involvement can contribute to the success of environmental initiatives through three main processes: (a) by nurturing and exploiting employees' tacit knowledge (Boiral, 2002); (b) by empowering employees to make suggestions for improvements or involving them in problem-solving activities (Govindarajulu \& Daily, 2004); (c) by developing a workplace culture which supports continuous efforts and improvements, for example, with the setting up of green teams (Govindarajulu \& Daily, 2004).

Hence, rather than management simply seeking employee compliance to the environmental initiatives, there is a need to engage and motivate employees to take responsibility for such initiatives. As evidence has shown, a supportive and nurturing behaviour on the part of the management in environmental initiatives may lead to increasing levels of employee engagement and commitment (Ramus \& Steger, 2000).

\subsubsection{Employee Training}

Appropriate green training is required to involve and engage employees in any environmental initiative. Some countries around the world have already invested significantly in green issues training to deal with waste, pollution and climate change. For example, in the United Kingdom $42 \%$ of organizations educate and train their employees to encourage a more pro-environmental behaviour (Phillips, 2007). Similarly, the United states have invested over $\$ 300 \mathrm{~m}$ in developing greener jobs (Barton, 2009). Hence, promoting employees' awareness, 
knowledge and skills in green issues can contribute to a greater extent to their emotional and material involvement in achieving environmental goals (Bansal \& Roth, 2000; Rothenberg et al., 2001).

Training, however, is not always successful (Jackson et al., 2011). Companies, in developing appropriate training programmes, have to take into account potential barriers and problems that could hamper their effectiveness. These may include inadequate assessment of training needs, poorly developed systems to re-train employees who have lost their jobs, and employees cynicism (Milliman \& Clair, 1996; Jackson et al., 2011).

\subsubsection{Environmental Awareness}

In order for training to be successful, companies should invest in building and developing an environmental knowledge base. While employees can be an important source of tacit knowledge in matters such as identifying pollution sources, developing ad-hoc solutions and managing emergency situations (Boiral, 2002), this knowledge is not often documented, stored and shared in appropriate ways across companies. However, a recent study about Chinese managers (Fryxell \& Lo, 2003) reveals that there is a strong link between environmental awareness and personal environmental behaviours. Therefore, environmental awareness is an important precursor of employees' green behaviour and can contribute to increase responsibility and responsiveness.

\subsubsection{Green Initiatives}

Green initiatives such as recycling, waste disposal, water and energy conservation, green building and paperless office are some of the ways in which companies try to embrace the idea of green working environment, that is, a workplace which is environmentally sensitive, resource efficient and socially responsible (SHRM 2008). In this way, managers can make their offices and practices more sustainable, efficient and well suited to the complex, ever-changing world of business. They can also enhance business profitability and long-run marketability, while reducing costs, increasing productivity and shareholder value in addition to benefiting the environment. Recent literature has indicated that green workplaces create more satisfied and productive employees (Fisk, 2000; Palmer \& Mariscal, 2002; Kumar \& Fisk, 2002; Miller \& Pogue, 2009; Singh et al., 2010; Smith \& Pitt, 2011; Armitage \& Murugan, 2013).

Green initiatives are often implemented together with the above mentioned HRM practices as a way to encourage and promote staff green behaviour. As Daily et al. (2009) have suggested it is important to foster all sort of technical and management skills among employees as away to implement effective green management systems in the workplace. However, the effectiveness of the green initiatives often depends on the leadership (Ramus \& Steger, 2000; Egri \& Herman 2000). The impact of exemplary pro-environmental behaviour by leaders and heads of departments plays an important role in the greening of organisations. As Robertson \& Barling (2013) argued, leaders influence their employees in the workplace by sharing values, offering inspiration and motivation, and by establishing a strong relationship with them.

\subsection{Research Questions}

The preceding literature has suggested certain practices that can play an important role in facilitating employees' green behaviour in the workplace. However, as mentioned before, these practices and the extent of their adoption and application is under-researched in the literature (Renwick et al., 2013). This study aims at better understanding the role and effectiveness of these practices and their impact on employees' green behaviour. Specifically, the study attempts to shed some light on the following questions:

- How do senior managers and lower level staff perceive the idea of green environment in the workplace?

- What practices/ initiatives do senior managers implement in the workplace to encourage employees' green behaviour?

- And, are these practices/ initiatives successful?

\section{Method}

\subsection{Procedure and Participants}

Data were collected from both senior managers and lower level staff at EnviroCo ( $N=1377)$. EnviroCo is a Saudi government agency that aims to serve the public and coordinate with other government agencies in various aspects. Caring for the safety and health of citizens and preserving the natural resources are among its goals. The selected agency is employing more than one thousand employees in administrative and technical tasks. It was established more than thirty years ago and is located in a rented building.

The questionnaire was distributed to all the staff at EnviroCo. In total 147 responses were attained, 32 from senior managers and 115 from lower level staff. The response rate was $11 \%$ which is in line with other studies on environmental sustainability and green behaviour. 
Table 1 displays the sample characteristics. The majority (84\%) of the respondents among the senior managers had more than 10 years work experience with $62 \%$ of them occupying managerial positions, and $38 \%$ of them occupying technical positions. The level of education is relatively high with respondents having respectively a bachelor (53\%), master $(19 \%)$ and $\mathrm{PhD}(25 \%)$. As regards the lower level staff sample, less than half (42\%) has more than 10 years work experience with $54 \%$ of the respondents holding a diploma.

Table 1. Sample characteristics

\begin{tabular}{|c|c|c|c|c|c|c|c|c|c|c|c|c|c|c|c|c|c|c|}
\hline \multirow[t]{4}{*}{ Type of sample } & \multirow{3}{*}{\multicolumn{2}{|c|}{ 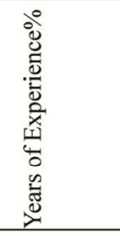 }} & \multirow[b]{3}{*}{ 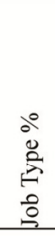 } & & \multicolumn{7}{|c|}{ Educational Level \% } & \multicolumn{7}{|c|}{ The functional level \% } \\
\hline & & & & & & & & & & & & \multicolumn{4}{|c|}{$\begin{array}{l}\text { Senior officials/ } \\
\text { Managers(N=32) }\end{array}$} & \multicolumn{3}{|c|}{ Staff $(\mathrm{N}=115)$} \\
\hline & & & & & 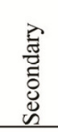 & $\begin{array}{l}\frac{\pi}{0} \\
\frac{0}{a} \\
\frac{a}{2}\end{array}$ & & 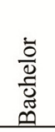 & 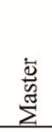 & بـ & $\begin{array}{l}\bar{\Xi} \\
\overline{0}\end{array}$ & 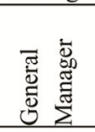 & $\begin{array}{l}\overline{5} \\
\text { on } \\
\text { E⿱ } \\
\Sigma\end{array}$ & 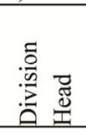 & 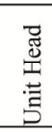 & 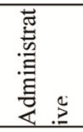 & 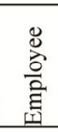 & $\begin{array}{l}\bar{\Xi} \\
\frac{\vec{t}}{2}\end{array}$ \\
\hline & 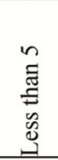 & 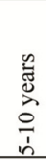 & 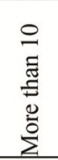 & 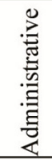 & 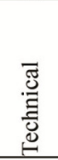 & & & & & & & 16 & 34 & 47 & 3 & 11 & 83 & 6 \\
\hline $\begin{array}{l}\text { Senior } \\
\text { Managers }(\mathrm{N}=32)\end{array}$ & 3 & 13 & 84 & 62 & 38 & & & 53 & 19 & 25 & 3 & & & & & & & \\
\hline Staff $(\mathrm{N}=115)$ & 22 & 35 & 42 & 44 & 56 & 13 & 54 & 25 & & & 8 & & & & & & & \\
\hline
\end{tabular}

\subsection{Questionnaire Design}

The research is based on a questionnaire which was sent to different departments and targeted senior managers and lower level employees. All questionnaires included two main sections. The first section of the questionnaire focused on the respondents' personal views towards the workplace environment. A second section of the questionnaire asked general questions about the respondents like years of experience, educational level, organizational level and job type. In the first section, a structured closed question approach was used to construct three main questions which included 34 statements and were similar in both senior managers and lower level staff questionnaires, except question one. The first question for senior managers was designed to explore their present views on the initiatives towards the adoption of the concepts and practices of green working environment The staff questionnaire, instead, was designed to capture their feelings about the work environment. In question two, respondents were asked about their views on the efforts put by the organization to help implementing green workplace practices. Finally, question 3 asked respondents about the appropriate methods which encourage employees to engage in green behaviour in the workplace environment. Responses for questions one and three were assessed using a 5-point Likert scale where 1=strongly disagree, 2=disagree, 3=neutral, 4=agree, $5=$ strongly agree. Question two required a response as follows: Yes, No and I don't know. Respondents filled the questionnaires anonymously and they were reassured about the confidentiality of their responses.

\subsection{Data Analysis}

Statistical analyses were performed using SPSS software. The participants' knowledge and views were analysed using descriptive statistics. Quantitative variables were pointed out as mean and standard deviation. The reliability of the scales was tested by Cronbach's alpha to confirm good internal correlation of each item in the scale. A Cronbach's alpha above 0.7 indicates a good internal reliability.

\section{Results}

Table 2 shows that the majority of senior managers seem to agree to some extent that the they are aware of the importance of protecting the work environment and of reducing the negative impact of the environment on the internal and external work practices respectively (Mean $=3.5, \mathrm{SD}=1.3$; Mean =3.3, $\mathrm{SD}=1.5$ ). However, this knowledge is not necessarily included when formulating long-term strategies and objectives for the company (Mean $=2.8, \mathrm{SD}=1.6$ ). Similarly, senior managers' efforts to disseminate knowledge about green working practices through training $($ Mean $=2.8, \mathrm{SD}=1.4$ ) or by nurturing environmental awareness $($ Mean $=2.8, \mathrm{SD}=$ 0.8 ) are only moderate. This seems to suggest that senior managers are aware of the importance of green behaviour in the workplace, but struggle to make it an integral part of the company's strategy and to implement working practices that would support and enhance employees' pro-environmental behaviour. On the other hand, senior managers seem to put a premium on certain initiatives such as the continuous assessment of the environmental health risks associated to erroneous practices and behaviours; employees' training on health and 
safety issues; green building and equipment maintenance; the use of email by staff; and the centralized storage of office supplies. All Cronbach's alphas of the statements are above 0.70 .

Table 2. Senior managers' views towards the concept and practices associated to green working environment

\begin{tabular}{|c|c|c|c|}
\hline Statement $^{\mathrm{a}}$ & Mean & $\begin{array}{l}\text { Std. } \\
\text { Deviation }\end{array}$ & $\begin{array}{l}\text { Cronbach's } \\
\text { alpha }\end{array}$ \\
\hline $\begin{array}{l}\text { Top management is aware of the importance of protecting the work environment and of } \\
\text { reducing the negative impact of the environment on the internal working practices. }\end{array}$ & 3.5 & 1.3 & 0.87 \\
\hline $\begin{array}{l}\text { Top management is aware of the importance of protecting the work environment and of } \\
\text { reducing the negative impact of the external environment work practices }\end{array}$ & 3.3 & 1.5 & 0.90 \\
\hline $\begin{array}{l}\text { Senior management is keen to integrate the concepts of green work environment when } \\
\text { formulating objectives and strategic decisions related to the presidency. }\end{array}$ & 2.8 & 1.6 & 0.84 \\
\hline $\begin{array}{l}\text { Senior management adopt different mechanisms for the dissemination of concepts and } \\
\text { behaviors of green work environment among employees }\end{array}$ & 2.8 & 1.4 & 0.73 \\
\hline $\begin{array}{l}\text { Senior management promote environmental awareness among staff about their responsibilities } \\
\text { towards the environment protection work }\end{array}$ & 2.8 & 0.8 & 0.81 \\
\hline $\begin{array}{l}\text { Top management is keen to conduct continuous assessment of the environmental health risks } \\
\text { arising from the behaviors and erroneous practices in the work environment to reduce the } \\
\text { impact on the internal and external environment }\end{array}$ & 3.8 & 1.1 & 0.74 \\
\hline $\begin{array}{l}\text { Top management direct their work and activities in the presidency towards the concepts and } \\
\text { practices of green working environment in order to improve the promotion of its image in the } \\
\text { community. }\end{array}$ & 3.8 & 1.1 & 0.86 \\
\hline Top management direct the working staff to use e-mail to reduce the amount of paper & 3.3 & 1.3 & 0.84 \\
\hline $\begin{array}{l}\text { The presence of safety and security system in the building of the presidency is one of the } \\
\text { green priorities to achieve a green working environment }\end{array}$ & 4.2 & 0.6 & 0.83 \\
\hline $\begin{array}{l}\text { Top management is keen to create conditions in the work environment to prevent the exposure } \\
\text { of employees to accidents and injuries }\end{array}$ & 4.2 & 0.6 & 0.79 \\
\hline $\begin{array}{l}\text { The presidency has training programmes for employees' health and safety and on the use of } \\
\text { PPP to secure their occupational health and safety }\end{array}$ & 4.2 & 0.6 & 0.93 \\
\hline $\begin{array}{l}\text { There are environmental records which record the dates of maintenance of the building and its } \\
\text { equipment and the extent of its conformity to the specifications of the building } \\
\text { environmentally friendly }\end{array}$ & 4.1 & 0.6 & 0.80 \\
\hline $\begin{array}{l}\text { The procurement management buy office supplies and business needs in large quantities } \\
\text { contributes to reduce packaging wastes }\end{array}$ & 3.8 & 0.6 & 0.77 \\
\hline $\begin{array}{l}\text { The centralized storage of office supplies to be shared between colleagues, to contribute to the } \\
\text { rationalization of consumption and prevent over-consumption }\end{array}$ & 4.0 & 0.6 & 0.85 \\
\hline $\begin{array}{l}\text { When buying computers and its accessories the energy efficiency of certified calibrator are } \\
\text { taken into account }\end{array}$ & 3.8 & 0.7 & 0.87 \\
\hline $\begin{array}{l}\text { Top management seriously consider the implementation of green building principles when } \\
\text { designing new buildings and the renewal of current buildings }\end{array}$ & 4.0 & 0.5 & 0.82 \\
\hline
\end{tabular}
Note. $\mathrm{N}=32 ;{ }^{a}$ Measured on a 5 -point scale 1 to 5 .

Looking at Table 3, lower level employees seem to recognize to some extent that senior managers are aware of the importance of a green working environment (Mean $=3.1, \mathrm{SD}=1.2$ ). They also agree that senior managers act to some extent to increase their environmental awareness (Mean $=2.7, \mathrm{SD}=1.2$ ) and they do so by detecting and stopping any wrong working practices (Mean $=2.8, \mathrm{SD}=1.2)$. Lower level staff are also aware to a great extent of the effects of their behaviour on productivity in the workplace (Mean $=3.6, \mathrm{SD}=1.0)$. The results point out that the majority of staff agree that the provision of a healthy work environment would help them to increase their productivity and their willingness to work for a longer time. Similarly, staff recognizes their personal responsibility in helping to protect the work environment from pollution through a number of initiatives, such as waste reduction and conservation of the resources available, and work to promote environmental awareness among colleagues. The Cronbach's alpha for these statements are above 0.70 . 
Table 3. Staff views towards the concept and practices of green workplace environment

\begin{tabular}{|c|c|c|c|}
\hline Statement $^{\mathrm{a}}$ & Mean & Std. Deviation & Cronbach's alpha \\
\hline $\begin{array}{l}\text { Top management is aware of the importance of protecting the work environment and of } \\
\text { reducing the negative impact of the environment on the internal and external labor } \\
\text { practices }\end{array}$ & 3.1 & 1.2 & 0.79 \\
\hline $\begin{array}{l}\text { Top management disseminate environmental awareness among staff of their } \\
\text { responsibility towards the protection of the environment while carrying out their work }\end{array}$ & 2.7 & 1.2 & 0.83 \\
\hline $\begin{array}{l}\text { Top management is keen to follow up on the wrong job practices in the work } \\
\text { environment in order to avoid the risks resulting from it }\end{array}$ & 2.8 & 1.2 & 0.85 \\
\hline $\begin{array}{l}\text { I know the environmental problems caused by the impact of malpractice on the work } \\
\text { environment }\end{array}$ & 3.6 & 1.0 & 0.91 \\
\hline I would like to work for a longer period if there is a healthy working environment & 4.0 & 1.1 & 0.77 \\
\hline The provision of a healthy work environment helps to increase my productivity & 4.6 & 0.6 & 0.71 \\
\hline $\begin{array}{l}\text { I have a personal responsibility to help protect the work environment from pollution } \\
\text { (such as reduction of waste and consumption of resources available) }\end{array}$ & 4.3 & 0.7 & 0.85 \\
\hline $\begin{array}{l}\text { I'm working on promoting environmental awareness among my colleagues to protect } \\
\text { the work environment }\end{array}$ & 3.9 & 0.9 & 0.87 \\
\hline I keep my email in paper & 2.7 & 1.2 & 0.74 \\
\hline I ration the use of paper by writing on the paper two-sides & 3.2 & 1.2 & 0.79 \\
\hline I tend to decrease font size to reduce the number of pages when you print paper & 3.4 & 1.2 & 0.82 \\
\hline Always turn off the lights when leaving the room or when there is sufficient daylight & 4.3 & 0.9 & 0.89 \\
\hline Make sure to turn off the air conditioning at the end of working hours & 3.9 & 1.1 & 0.86 \\
\hline Turn off the computer (printers, cameras, etc.) before leaving the work area or the office & 4.3 & 0.9 & 0.90 \\
\hline Make sure to reduce the water consumption rate in the work environment & 4.3 & 0.9 & 0.87 \\
\hline $\begin{array}{l}\text { I'm trying to reduce the consumption of bottled mineral water in small plastic containers } \\
\text { depending on the large water coolers }\end{array}$ & 3.6 & 1.0 & 0.74 \\
\hline
\end{tabular}

Note. $\mathrm{N}=115 ;{ }^{a}$ Measured on a 5 -point scale 1 to 5 .

The questionnaire also further explored the green work environment practices put in place at EnviroCo. The responses are summarized in Tables 4 and 5. When asked about which methods are more successful in encouraging staffs to be pro-environmental, both senior managers and lower level staff seem to emphasize the importance of effective leadership, the promotion of awareness through training and the setting up of green teams, the involvement and participation of employees in green activities such as problem solving, the conservation of resources and the adoption of international environmental standards.

Table 4. Senior managers' views on the appropriate methods that encourage employees' green bahaviour

\begin{tabular}{|c|c|c|c|}
\hline Statement $^{\mathrm{a}}$ & Mean & Std. Deviation & Cronbach's alpha \\
\hline $\begin{array}{l}\text { Effective promotion by senior management and directors of departments to the staff to apply } \\
\text { the practices of green behavior in the work environment (financial rewards, certificates of } \\
\text { appreciation .....) }\end{array}$ & 4.3 & 1.1 & 0.91 \\
\hline Design programs for setting up green work environment teams & 4.3 & 0.8 & 0.87 \\
\hline $\begin{array}{l}\text { Internal awareness in the presidency to encourage green behavior in the work environment } \\
\text { and campaigns (training courses, lectures, and a seminar for employees, workshops and } \\
\text { forums) }\end{array}$ & 4.5 & 0.9 & 0.82 \\
\hline $\begin{array}{l}\text { Providing technology that helps environmental practices (green technology, electronic } \\
\text { lighting, means saving energy and water, reduce waste) }\end{array}$ & 4.3 & 0.8 & 0.76 \\
\hline $\begin{array}{l}\text { One of the indicators to be exercised over the employee's performance evaluation of the } \\
\text { application of the principles of green work environment }\end{array}$ & 3.8 & 1.0 & 0.71 \\
\hline $\begin{array}{l}\text { Design competitions at the departmental level by applying the concept of green work } \\
\text { environment }\end{array}$ & 4.1 & 0.9 & 0.81 \\
\hline Administration is keen to get the ISO 1400 certificate for environmental management & 4.0 & 0.8 & 0.90 \\
\hline Determine the system of penalties for non-compliance practices of green work environment & 3.9 & 0.8 & 0.73 \\
\hline
\end{tabular}

Note. $\mathrm{N}=32 ;{ }^{\text {a }}$ Measured on a 5 -point scale 1 to 5 . 
Table 5. Lower level employees' views on the appropriate methods that encourage employees' green bahaviour

\begin{tabular}{|c|c|c|c|}
\hline Statement $^{\mathrm{a}}$ & Mean & Std. Deviation & Cronbach's alpha \\
\hline $\begin{array}{l}\text { Effective motivation of staff by senior management and directors of departments for the } \\
\text { adoption of green behavior practices in the work environment (financial rewards, } \\
\text { certificates of appreciation .....) }\end{array}$ & 4.3 & 0.9 & 0.88 \\
\hline Design programs on the preparation of the green work environment teams & 4.3 & 0.9 & 0.85 \\
\hline $\begin{array}{l}\text { Internal awareness in the presidency to encourage green behavior in the work } \\
\text { environment and campaigns (training courses, lectures, and seminars for employees, } \\
\text { workshops and forums) }\end{array}$ & 4.3 & 1.0 & 0.79 \\
\hline $\begin{array}{l}\text { Provide the technology that helps environmental friendly practices (green technology, } \\
\text { electronic lighting, means saving energy and water, reduce waste) }\end{array}$ & 4.3 & 1.1 & 0.72 \\
\hline $\begin{array}{l}\text { One of the employees promotion evaluating indicators would be an evaluation of his } \\
\text { green behavior }\end{array}$ & 4.1 & 1.0 & 0.91 \\
\hline $\begin{array}{l}\text { Design competitions between the different departments on their adoption to green work } \\
\text { environment concepts }\end{array}$ & 4.1 & 1.1 & 0.87 \\
\hline $\begin{array}{l}\text { The administration is keen to get the ISO } 1400 \text { certification by implementing } \\
\text { environmental management }\end{array}$ & 4.0 & 1.0 & 0.81 \\
\hline Set up of penalizing measures for non compliance with green practices by the personnel & 3.8 & 1.1 & 0.77 \\
\hline
\end{tabular}

Note. $\mathrm{N}=115 ;{ }^{a}$ Measured on a 5 -point scale 1 to 5 .

\section{Discussion and Conclusion}

This study examined the perceptions of senior managers and lower level employees at EnviroCo with respect to the idea of green working environment and the extent to which a number of practices are used by senior managers to promote green behaviour in the workplace. In summary, the organization appears to be sympathetic with the idea of green working environment as reflected by senior managers' endorsement. However, the findings also indicate that senior managers are not using effectively HRM practices to encourage employees' green behaviour and do not necessarily include them in the long-term strategy and planning of their organization. As Ramus \& Steger (2000) have shown, other management-related issues may be more important than environmental sustainability. Thus, EnviroCo could be more active in promoting pro-environmental behaviour.

A key issue revolves around senior managers' low involvement, effectively only narrowly supporting green behaviour. This suggests that managers could play a much more active role in providing guidelines and standards that motivate staff and encourage them to engage in environmental initiatives. Both the literature and empirical research (Robertson \& Barling, 2013) suggest that managers' involvement is influential in fostering employees' green behaviour. Furthermore, managers' active involvement can become the starting point for the development of practices such as training, environmental awareness and employee involvement which respondents in the questionnaire seem to consider of utmost importance. These practices may then serve to reinforce and encourage employees' green behaviour.

A second issue regards the weak deployment of HRM practices which could support employees' pro-environmental behaviour such as training, raising environmental awareness and actual employees' involvement. Only by providing education and training, employees can learn how to foster and enact environmental changes and become aware of their organization's efforts toward sustainability. Indeed, employees who are better acquainted with companies' practices and policies are more likely to contribute to their organization sustainability programmes (Ramus, 2002). Moreover, managers should further support pro-environmental behaviour by promoting initiatives such as waste reduction, water and energy conservation, paperless office and green building. This can be achieved only if managers act as role models with regard to these initiatives and motivate and inspire employees to act pro-environmentally.

More generally, the questionnaire findings seem to point out a misalignment between research and practice. While the literature highlights the key role of HRM practices in supporting environmental sustainability, this research shows that EnviroCo is not using such practices to a great extent or effectively. This suggests that the organization could introduce and further develop HRM practices to promote green behaviour among their staff. In this respect, increasing knowledge and information about sustainable behaviour can play an important role in making staff more active and competent in green practices. This can be achieved not only at the organizational level, but most importantly at the institutional level. Indeed, governments and educational institutions are critical actors in promoting and fostering environmental awareness. This, for example, can be achieved through campaigns about recycling, composting, toxicity of certain materials and energy saving devices. With specific reference to the Kingdom of Saudi Arabia (KSA), the government is moving in this direction by integrating the 
environmental aspect in the curriculum for primary and secondary education. Its primary goal is to ensure that education has an impact on the community by enabling children and youth to gain skills and values that are connected to environmental problems and responsibilities. At the same time, through education, the government is also keen on promoting the citizens' psycho-social wellbeing so that they can live a good life in a healthy environment. This can be attained not only by creating more job opportunities and sustaining the growth of the local economy, but also by restoring and protecting all the natural resources in the environment.

In addition to the above, environmental awareness can be further sustained and promoted by governments and educational institutions through research aimed at developing novel eco-friendly technologies. The usage of cleaner production techniques, for example, has been beneficial for both the environment and businesses in general. While businesses have taken advantage of these new technologies in terms of cost savings, the environment has benefited through reduced wastage, energy used and greenhouse emissions. Hence, new technologies together with citizens increased knowledge about the environment can help the spread of pro-environmental behaviour within companies and in the society.

The research is not without limitations. One potential limitation is that this study explored the relationship between leadership, HRM practices and green behaviour in the workplace in a single organization. Future surveys should collect data from companies belonging to different sectors so to make results more generalizable. A second potential limitation has to do with the limited insights gained about the extent to which employees are likely to engage in green behaviour when they receive support from senior managers. Future studies should aim to address this issue as results could offer guidance to managers in relation to how to tailor HRM practices and enhance the sustainability of their organizations. Despite these limitations, however, this research provides some interesting results about the perceived importance of pro-environmental bahaviour in the workplace in Saudi Arabia.

\section{References}

Aguinis, H., \& Glavas, A. (2012). What we know and don't know about corporate social responsibility: A review and research agenda. Journal of Management, 38, 932-968.

Andersson, L. M., Jackson, S. E., \& Russell, S. V. (2013). Greening organizational behavior: An introduction to the special issue. Journal of Organizational Behavior, 34, 151-155.

Armitage, L., \& Murugan, A. (2013). The human green office experience: Happy and healthy or sick and frustrated? The Australian and New Zealand Property Journal, 4(1), 35-41.

Bansal, P., \& Roth, K. (2000). Why companies go green: A model of ecological responsiveness. Academy of Management Journal, 43, 717-736.

Barling, J., Christie, A., \& Hoption, C. (2010). Leadership. In S. Zedeck (Ed.), APA handbook of industrial and organizational psychology (Vol. 1). Washington, DC: American Psychological Association.

Barton, R. (2009). Is the grass any greener? The Independent on Sunday (15th November, pp. 8-13).

Boiral, O. (2002). Tacit knowledge and environmental management. Long Range Planning, 35, 291-317.

Cox, A., Higgins, T., Gloster, R., Foley, B., \& Darnton, A. (2012). The impact of workplace initiatives on low $\begin{array}{lllll}\text { carbon } & \text { behaviours. } & \text { Edinburgh, } & \text { UK. } & \text { Retrieved }\end{array}$ http://www.scotland.gov.uk/Resource/0039/00390309.pdf

Daily, B. F., Bishop, J. W., \& Govindarajulu, N. (2009). Conceptual model for organizational citizenship behavior directed toward the environment. Business \& Society, 48, 243-256.

Darnall, N., \& Sides, S. (2008). Assessing the performance of voluntary environmental programs: Does certification matter? Policy Studies Journal, 36, 95-117.

Denton, K. D. (1999). Employee involvement, pollution control and pieces to the puzzle. Environmental Management and Health, 10(2), 105-111.

Egri, C. P., \& Herman, S. (2000). Leadership in the North American environmental Sector: values, leadership styles, and contexts of environmental leaders and their organizations. Academy of Management Journal, 43, 571-604.

Fisk, W. J. (2000). Health and productivity gains from better indoor environments and their relationship with building energy efficiency. Annual Review of Energy and the Environment, 25(1), 537-66.

Florida, R., \& Davidson, D. (2001). Gaining from green management: Environmental management systems inside and outside the factory. California Management Review, 43(3), 64-84. 
Fryxell, G. E., \& Lo, C. W. H. (2003). The influence of environmental knowledge and values on managerial behaviours on behalf of the environment: An empirical examination of managers in China. Journal of Business Ethics, 46, 45-69.

Govindarajulu, N., \& Daily, B. F. (2004). Motivating employees for environmental improvement. Industrial Management and Data Systems, 104, 364-372.

Huffman, A. H., Watrous-Rodriguez, K. M., Henning, J. B., \& Berry, J. (2009). "Working" through environmental issues: The role of the I/O psychologist. The Industrial-Organizational Psychologist, 47, 27-35.

Jabbour, C. J. C., \& Santos, F. C. A. (2008). The central role of human resource management in the search for sustainable organizations. The International Journal of Human Resource Management, 19, 2133-2154.

Jackson, S. E., \& Seo, J. (2010). The greening of strategic HRM scholarship. Organizational Management Journal, 7, 278-290.

Jackson, S. E., Renwick, D. W. S., Jabbour, J. C., \& Muller-Camen, M. (2011). State-of-the-art and future directions for green human resource management: Introduction to the special issue. German Journal of Research in Human Resource Management, 25, 99-116.

Kumar, S., \& Fisk, W. J. (2002). Promoting Workplace Productivity and Health: Final Report Lawrence. Berkeley National Laboratory, Berkeley, CA.

May, D. R., \& Flannery, B. L. (1995). Cutting waste with employee involvement teams. Business Horizons, 38, 28-38.

Miller, N., \& Pogue, D. (2009). Do Green Buildings Make Dollars and Sense? University of San Diego: Burnham-Moores Center for Real Estate.

Milliman, J., \& Clair, J. (1996). Best environmental HRM practices in the U.S. In W. Wehrmeyer (Ed.), Greening People: Human Resources and Environmental Management (pp. 49-73). Sheffield: Greenleaf Publishing.

Olson, E. G. (2008). Creating an enterprise-level "green" strategy. Journey of Business Strategy, 29(2), 22-30.

Ones, D. S., \& Dilchert, S. (2012). Environmental sustainability at work: A call to action. Industrial and Organizational Psychology: Perspectives on Science and Practice, 5, 503-511.

Palmer, M., \& Mariscal, A. (2002). Green Buildings and Worker Productivity: Review of the Literature. San Francisco Environment, San Francisco, CA.

Phillips, L. (2007). Go green to gain the edge over rivals. People Management, 23, 9.

Ramus, C. A. (2002). Encouraging innovative environmental actions: What companies and managers must do. Journal of World Business, 37, 151-164.

Ramus, C. A., \& Steger, U. (2000). The roles of supervisory support behaviors and environmental policy in employee ecoinitiatives at leading-edge European companies. Academy of Management Journal, 43, 605-626.

Renwick, D. W. S., Redman, T., \& Maguire, S. (2013). Green human resource management: A review and research agenda. International Journal of Management Reviews, 15, 1-14.

Robertson, J. L., \& Barling, J. (2013). Greening organizations through leaders' influence on employees' pro-environmental behaviors. Journal of Organizational Behavior, 34, 176-194.

Rothenberg, S., Pil., F. K., \& Maxwell, J. (2001). Lean, green, and the quest for superior environmental performance. Production and Operations Management, 10, 228-243.

Russell, S. V., \& Griffiths, A. (2008). The role of emotions in driving pro- environmental behaviours. In W. Zerbe, N. M. Ashkanasy, \& C. E. J. Härtel (Eds.), Managing Emotions in the Workplace (pp. 83-107). New York: Sharpe.

Singh, A., Syal, M., Grady, S., \& Korkmaz, S. (2010). Effects of Green Buildings on Employee Health and Productivity. American Journal of Public Health, 100(9), 1665-1668.

Smith, A., \& Pitt, M. (2011). Sustainable workplaces and building user comfort and satisfaction. Journal of Corporate Real Estate, 13(3), 144-156.

Society for Human Resource Management (SHRM). (2008). Green Workplace. Retrieved from 
http://web1.ctaa.org/webmodules/webarticles/articlefiles/18_SHRMsurvey.pdf.retrevied 25-6-2016

Steg, L., \& Vlek, C. A. J. (2009). Encouraging pro-environmental behaviour: an integrative review and research agenda. Journal of Environmental Psychology, 29, 309-317.

Stringer, L. (2009). The Green Workplace: Sustainable Strategies that Benefit Employees, the Environment, and the Bottom Line. Palgrave Macmillan: United Kingdom

Zibarras, L., \& Ballinger, C. (2011). Promoting environmental behavior in the workplace: A survey of UK organizations. In D. Bartlett (Ed.), The psychology of sustainability in the workplace (pp. 84-90). London: BPS.

\section{Copyrights}

Copyright for this article is retained by the author(s), with first publication rights granted to the journal.

This is an open-access article distributed under the terms and conditions of the Creative Commons Attribution license (http://creativecommons.org/licenses/by/4.0/). 